\title{
PERCEPATAN MASA PENGGUNAAN SONDE MELALUI STIMULASI NON NUTRITIVE SUCKING DALAM PEMBERIAN MINUM BAYI PREMATUR
}

\author{
Nurhayati $^{1,2^{*}}$, Dessie Wanda $^{3}$, Elfi Syahreni ${ }^{3}$ \\ 1. Rumah Sakit Anak Bunda Harapan Kita, Jakarta Barat 11420, Indonesia \\ 2. Program Studi Magister Fakultas Ilmu Keperawatan, Universitas Indonesia, Depok 16424, Indonesia \\ 3. Fakultas Ilmu Keperawatan Universitas Indonesia, Kampus, Depok, 16424, Indonesia \\ *E-mail: nur.eko36@yahoo.com
}

\begin{abstract}
Abstrak
Kemampuan mengisap mengisapbayi prematur dapat ditingkatkan dengan pemberian stimulasi non nutritive sucking (NNS) dengan menggunakan empeng. Penelitian ini bertujuan untuk membuktikan pengaruh stimulasi NNS menggunakan empeng terhadap lama penggunaan sonde dalam pemberian minum bayi prematur. Desain penelitian menggunakan kuasi eksperimen dengan post test only with control group design dengan sampel dua puluh responden untuk dua kelompok yang dipilih secara purposive sampling di salah satu rumah sakit daerah Tangerang. Pengumpulan data menggunakan kuesioner dan instrumen lembar observasi indikator pelepasan sonde dan dianalisis dengan uji t tidak berpasangan. Hasil penelitian menunjukkan tidak ada pengaruh stimulasi NNS dengan menggunakan empeng terhadap lama penggunaan sonde dalam pemberian minum bayi prematur $(p=0,379)$, tetapi masa penggunaan sonde lebih pendek. Peneliti merekomendasikan agar stimulasi NNS dengan menggunakan empeng tetap dijadikan prosedur alternatif untuk meningkatkan refleks mengisapmengisap pada bayi prematur.
\end{abstract}

Kata kunci: empeng, prematur, refleks mengisap, stimulasi non nutritive sucking, sonde

\begin{abstract}
Acceleration of Gastric Tube Usage through Non Nutritive Sucking Simulation for Premature Infant Feeding. An adequate sucking can be improved a premature infant's sucking reflex with non nutritive sucking stimulation (NNS) with pacifier. The purpose of this research was to identify the influence of NNS stimulation with pacifier towards the duration of gastric tube usage during premature infant feeding. The design of this research was quasi experimental with post test only control group design with 20 respondents for two groups, then were chosen by purposive sampling in one of Tangerang District Hospital. The data were collected using a questionnaire and an observation form. Data were analized using independent $t$ test. The result of this research showed that there was no influence of NNS with pacifier towards the duration of gastric tube usage $(p=0,379)$, however the duration of gastric tube usage was shortened. This research recommends that non nutritive sucking stimulation with pacifier is an alternative procedures to improve a premature infant's sucking reflex.
\end{abstract}

Keywords: non nutritive sucking stimulation, preterm babies, pacifier, sucking reflex, gastric tube

\section{Pendahuluan}

Prematuritas merupakan salah satu penyebab kematian neonatus tertinggi (Blencowe, et al., 2012). Kondisi prematur sering berdampak pada kesehatan anak di kemudian hari yaitu berupa gangguan pertumbuhan dan perkembangan (Judarwanto, 2012). Penelitian yang dilakukan oleh Gewolb dan Vice (2006) melaporkan bahwa masa gestasi yang kurang dapat menyebabkan gangguan koordinasi antar refleks mengisap, menelan dan bernapas, sehingga dapat terjadi penundaan pemberian air susu ibu (ASI). Pemberian ASI yang terlambat dapat mengakibatkan berat badan bayi sulit naik dan dehidrasi pada minggu pertama kehidupannya.

Bayi prematur belum mempunyai kemampuan minum yang adekuat. Ketidakmampuan minum pada bayi prematur disebabkan oleh kemampuan otot mengisapmengisap masih lemah, kapasitas 
oral belum stabil, dan penyebab yang berhubungan dengan gangguan neurologi. Keefektifan koordinasi antara refleks mengisap, menelan, dan bernapas pada bayi prematur dipengaruhi oleh kematangan struktur otak dan saraf kranial (Da Costa, van den Engel-Hoek, \& Bos, 2008; Glass \& Wolf, 1994).

Kemampuan mengisap dan menelan bayi prematur dapat ditingkatkan dengan melakukan stimulasi oral motor dini dan non nutritive sucking (NNS) (Lau, Alagugurusamy, Shulman, Smith, \& Schanler, 2000). NNS merupakan aktivitas mengisap bayi tanpa adanya cairan atau nutrisi dan merupakan terapi non farmakologis dengan menggunakan empeng yang bertujuan untuk merangsang kemampuan mengisap tanpa pemberian ASI atau formula (Kenner \& McGrath, 2004; Merenstein \& Gardner, 2002).

Beberapa penelitian terkait stimulasi oral dan NNS telah dilakukan, antara lain penelitian yang dilakukan Cevasco dan Grant (2005). Hasil penelitian yang dilakukan Cevasco dan Grant menunjukkan bahwa intervensi NNS dan mendengarkan musik lima belas menit sebanyak tiga kali pada enam puluh dua bayi usia gestasi 32-36 minggu meningkatkan berat badan bayi prematur. Penelitilain, Lessen (2011) melaporkan bahwa stimulasi oral (premature infant oral motor intervention) telah membuktikan kemampuan minum bayi lima hari lebih cepat dan dapat pulang dua sampai dengan tiga hari lebih cepat. Stimulasi oral dilakukan lima menit sehari, selama tujuh hari pada sembilan belas bayi prematur dengan usia gestasi 26-29 minggu.

Penggunaan empeng (NNS) yang telah banyak dilakukan pada pelayanan keperawatan adalah untuk memberikan rasa nyaman pada bayi. Penggunaan empeng sebagai cara meningkatkan refleks mengisap bayi masih jarang ditemukan. Penelitian ini bertujuan untuk mengetahui sejauh mana pengaruh stimulasi NNS dengan menggunakan empeng terhadap lama penggunaan sonde dalam pemberian minum bayi prematur.

\section{Metode}

Rancangan penelitian ini menggunakan eksperimen semu menggunakan kelompok kontrol. Data diambil dengan sekali pengukuran dan sampel ditentukan secara non probability sampling dengan teknik purposif. Jumlah responden adalah dua puluh bayi yang didapatkan dari penghitungan besar sampel berdasarkan rumus uji hipotesis beda dua mean kelompok independen. Kriteria inklusi penelitian ini adalah usia gestasi bayi antara tiga puluh satu sampai dengan tiga puluh tujuh minggu, mendapat persetujuan dari orang tua, bayi sudah tidak mendapat terapi infus total, masih minum memakai sonde, suhu tubuh antara 36,5 sampai dengan $37,5^{\circ} \mathrm{C}$, serta bayi tidak dalam kondisi gangguan napas dan kondisi sakit berat, seperti perdarahan otak, kelainan jantung, kelainan bedah serta kelainan kongenital. Penentuan kelompok intervensi dan kelompok kontrol dilakukan secara acak sederhana.

Alat pengumpul data yang digunakan dalam penelitian ini adalah kuesioner dan lembar observasi indikator pelepasan sonde. Kuesioner digunakan untuk mendapatkan data karakteristik bayi prematur dan lembar observasi indikator pelepasan sonde (berupa pencatatan hasil pengukuran berat badan bayi dan kemampuan minum bayi per oral). Instrumen penelitian ini adalah lembar observasi indikator pelepasan sonde, validitas isi instrumen telah dikonsulkan kepada pakar di bidang keperawatan neonatus. Uji reliabilitas instrumen menggunakan uji Cronbach alpha dengan nilai alpha sebesar 0,74.

Uji interrater reliability menggunakan uji Cohen's Kappa menghasilkan nilai Kappa sebesar satu. Peneliti melakukan stimulasi NNS menggunakan empeng lima menit sebelum bayi minum, sebanyak tiga kali sehari dan selama tujuh hari. Jumlah ASI atau formula yang dapat diminum bayi melalui oral dan hasil penimbangan berat badan dicatat pada lembar observasi. Intervensi stimulasi NNS telah dilakukan dengan memperhatikan prinsip-prinsip etik, yaitu respect for human dignity, beneficence, dan justice.

Analisis data dilakukan menggunakan program komputer dan uji yang dilakukan adalah uji $t$ tidak berpasangan untuk mengetahui pengaruh stimulasi NNS dengan menggunakan empeng terhadap lama penggunaan sonde. Tempat pene- 
litian dilakukan di ruang perinatologi di salah satu rumah sakit daerah Kabupaten Tangerang.

\section{Hasil}

Gambaran karakteristik responden pada penelitian ini sebagian besar memiliki berat badan antara 2.000 sampai dengan 2.500 gram (40\%), rerata usia gestasi tiga puluh tiga minggu dengan nilai APGAR 4,9, dan jenis kelamin seimbang antara lelaki dan perempuan.

Hasil analisis statistik menunjukkan bahwa tidak ada pengaruh stimulasi NNS dengan menggunakan empeng terhadap lama penggunaan sonde dalam pemberian minum bayi prematur $(\mathrm{p}=0,379)$. Penelitian ini menunjukkan bahwa masa penggunaan sonde pada kelompok intervensi lebih cepat dari pada kelompok kontrol (Tabel 1).

\section{Pembahasan}

Hasil penelitian ini menunjukkan bahwa tidak ada pengaruh stimulasi NNS dengan menggunakan empeng terhadap lama penggunaan sonde. Hal ini tidak sejalan dengan penelitian yang dilakukan Cevasco dan Grant (2005), yang melaporkan bahwa stimulasi NNS dan mendengarkan musik dapat meningkatkan berat badan. Lessen (2011) juga melaporkan bahwa stimulasi oral yang dilakukan telah dapat meningkatkan minum per oral lima hari lebih cepat dan bayi dapat pulang 2,6 hari lebih cepat. Peneliti mengasumsikan bahwa ketidaksesuaian hasil ini disebabkan oleh perbedaan besarnya sampel yang sangat bervariasi, adanya kombinasi stimulasi yang dilakukan, dan durasi serta frekuensi stimulasi yang berbeda.

Meskipun hasil penelitian menunjukkan tidak ada pengaruh yang bermakna, namun secara kuantitas terdapat perbedaan lama penggunaan sonde antara kelompok yang diberi stimulasi NNS dan yang

Tabel 1. Perbedaan Lama Penggunaan Sonde dalam Pemberian Minum Bayi Prematur $(\mathrm{n}=10)$

\begin{tabular}{lcc}
\hline Variabel & Rerata & p \\
\hline Lama penggunaan sonde & & \\
a. Kelompok Intervensi & 4,7 & 0,379 \\
b. Kelompok Kontrol & 6 & \\
\hline
\end{tabular}

tidak mendapat stimulasi. Stimulasi NNS dapat dilakukan untuk meminimalkan terjadinya gangguan refleks mengisap pada bayi prematur sehingga pelepasan sonde dapat dipercepat.

Hubungan usia gestasi terhadap lama penggunaan sonde pada penelitian ini menunjukkan hubungan yang bermakna. Hasil penelitian sejalan dengan penelitian yang dilakukan Raju, Higgins, Stark, dan Levano (2006), yang menjelaskan bahwa usia gestasi memengaruhi kematangan organ. Da Costa, Hoek, dan Bos (2008) juga menjelaskan bahwa kematangan struktur otak dan saraf kranial memengaruhi keefektifan koordinasi refleks mengisap, menelan dan bernapas pada bayi prematur. Refleks mengisap dipengaruhi oleh kematangan fungsi otak, semakin muda usia gestasi, fungsi organ tubuh semakin kurang, sehingga refleks mengisap juga belum adekuat.

Hubungan berat badan terhadap lama penggunaan sonde pada penelitian ini bermakna. Hasil penelitian ini sejalan dengan Cevasco dan Grant (2005) yang melaporkan bahwa stimulasi NNS dengan mendengarkan musik dapat meningkatkan berat badan. Kenaikan berat badan merupakan salah satu indikator peningkatan status pertumbuhan bayi. Peningkatan pertumbuhan ini membantu proses pematangan organ tubuh, termasuk kemampuan refleks mengisap bayi.

Selain itu, tidak ditemukan adanya hubungan antara jenis kelamin terhadap lama penggunaan sonde. Studi literatur yang mengatakan perbedaan refleks mengisap antara jenis kelamin laki dan perempuan belum ada.

\section{Kesimpulan}

Penelitian ini menunjukkan bahwa tidak ada pengaruh stimulasi NNS dengan menggunakan empeng terhadap lama penggunaan sonde dalam pemberian minum bayi prematur. Namun, lama penggunaan sonde pada Kelompok Intervensi lebih pendek daripada Kelompok Kontrol. Berdasarkan hal tersebut, perawat dapat dimotivasi untuk lebih berperan dalam meningkatkan refleks mengisap dengan cara melakukan sosialisasi dan edukasi pentingnya stimulasi NNS pada bayi prematur (NN, INR, AM). 


\section{Referensi}

Blencowe, H., Cousens, S., Oestergaard, M., Chou, D., Moller, A.B., Narwal, R., \& Lawn, J.E. (2012). National, regional, and worldwide estimates of preterm birth. The Lancet, 9, 2162-2172. Diperoleh dari http://www. WHO.Int.com.

Cevasco, A.M., \& Grant, R.E. (2005). Effect of pacifier activated lullaby on weight gain of premature infants. Journal of Music Therapy, 42 (2), 123.

Da Costa, S. P., van den Engel-Hoek, L., \& Bos, A. F. (2008). Sucking and swallowing in infants and diagnostic tools. Journal of Perinatology, 28, 247-257.

Gewolb, I., \& Vice, F. (2006). Maturational changes in rhythms, patterning and coordination of respiration and swallow during feeding in preterm and infants. Dev Med Child Neurol, 48, 568-594.

Glass, R.P., \& Wolf, L.S. (1994). A global perspective on feeding assessment in the neonatal intensive care unit. The American Journal of Occupational Therapy, 48 (6), 514-526.

Judarwanto, W. (2012). Bayi prematur beresiko alergi dan hipersensitifitas saluran cerna. Jakarta: Grow Up Clinic Information Education Network.
Kenner, C., McGrath, J. M. (2004). Developmental care of newborn and infants: A guide for health professionals. New York: Elsevier.

Lau, C., Alagugurusamy, R., Schanler, R. J., Smith, E. O., \& Shulman, R. J. (2000). Characterization of the developmental stages of sucking in preterm infant during bottle feeding. Acta Paediatric, 89, 846852.

Lessen, B. S. (2011). Effect of the premature infant oral motor intervention on feeding progression and length of stay in preterm infants. Advances in Neonatal Care, 11 (2), 129-139.

Merenstein, G.B., \& Gardner, S.L. (2002). Handbook of neonatal intensive care (5th Ed.). St. Louis, Missouri: Mosby.

Raju, T.N.K., Higgins, R.D., Stark, A.R., \& Leveno, K.J. (2006). Optimizing care and outcome for late preterm (near term) infants: A summary of the workshop sponsored by the National Institute of Child Health and Human Development. Pediatrics, 118, 1207-1214. 